\title{
Legal Aspect of Jain Religion as separate entity
}

\author{
Vaibhav Jain ${ }^{1}$, Sanjay Jain ${ }^{2}$ \\ ${ }^{I} B B A-L L B$ Scholar, ICFAI University, Dehradun, India \\ ${ }^{2}$ Department of Mathematical Sciences, Government College, Ajmer, India
}

\begin{abstract}
Voltaire once expressed his belief in the following words, "I may not agree with what you say but I will defend to the death your right to say it." Jain's should not be cover under the realm (or judge under the) of Hindu laws (the laws which apply to Hindus and which consist of set of laws which are related to personal matters). Intellectualism however plays an important role in this regard, as the outsider's perception; it is the perspective form which one may see and observe that which insider player cannot notice, realize and recognize; for the latter are captivated by their own views, beliefs and assumption; they are hostages of their own world. In this paper, we are not interested in lecturing the meaning of Jainism, nor we aiming to analyze legislators thinking and decision in any case, to be faithfully and professionally addressed, each of these institutions require more than one manuscript, further conferences, additional symposiums and above all not only intellectual but rather professional experts in each of these fields. Our work is present to seek and underline problems that legislation done at the time of drafting of Hindu laws and also regards such behavior to be hippo critical to notions that Jainism is an offshoot or part and parcel of Hinduism. Here we studies that Jain law developed by Jain law- makers (Jain Tirthankars and teachers) is more suitable for Jainism related to adoption, succession and partition etc., over Hindu laws. Hindu laws are based on work of manu (manusmriti) but Jain have their own legal work in the book vardhmanneeti by hemchandra ji and some other religious texts (kalpa sutra etc), according to Jainism rishabhdev the first trithankar of jain's which lives in Indus valley civilization are the first law giver and to took Jains under the realm of Hindu laws is not satisfied.
\end{abstract}

Keywords: Hindu Law, Jainism, Jain Law, Religion, Tirthankaras.

\section{Prologue}

Jainism has basically an ideology which is non-believer of bedrock forming of Hindus. If Jain's are not given separate legal identity and practicing their personal laws according to their religion then it will overshadowed or engulf by Hinduism. Many legislators and other scholars believe that Jainism is an offshoot of Hinduism that is the reason that they cover it under the supremacy of hindu laws. Even Jains and Hindus don't have any same festival (diwali in Jain sense is made because of nirvana (enlightment) of lord mahavir).

As there was in the school [1], it is written that Jainism was founded by lord mahavir which is not true as:

Ancient history of India reveals that there were three major religions in India. They were the Brahaminism, the Buddhism and the Jainism (Nirgranthas). Latest research and excavation at Mohenjodaro and Harappa has shown that the Jainism existed five thousand years ago; however the Jains believe it to be eternal. "There is truth in the Jain idea that their religion goes back to a remote antiquity, the antiquity in question being that of the preAryan, so called Dravidian illuminated by the discovery of a series of great late stone-age cities in Indus valley, dating back to third and perhaps even fourth millennium B. C." [2]

Pre-Aryan Roots: Almost all the scholars agree that Jainism has Pre-Aryan roots in the cultural history of India. As Dr. A. N. Upadhye remarked -- "The origins of Jainism go back to the pre-historic times. They are to be sought in the fertile valley of Ganga, where they flourished in the past, even before the advent of Aryans with their priestly religion, a society of recluses who laid much stress on individual exertion, on practice of a code of morality and devotion to austerities, as means of attaining religious Summum Bonum." [3]

In the same vein Joseph Campbell, commented "Sankhya and Yoga represented a later psychological sophistication of principles preserved in Jainism. They together are theory and practice of a single philosophy." [4] Other scholars such as Prof. Buhler[5], H. Jacobi, J.G.R. Forlong, Dr. Hornell, Pt. Sukhalalji, Prof. Vidyalankara, Acharya Tulasi, Prof. G.C.Pandey and others believe that Jainism is one of the earliest known religious systems prevailing in India amongst the non-Aryan races which belonged to Indus valley civilization.

\section{Introduction}

Jains have their own distinct history of laws and have their own sources and origins of laws some may coincide with Hindus but they differ from the Hindus in their conduct towards the dead; omitting all obsequies after corps is burnt or buries and also rejects the scriptural character of the Vedas and repudiated the Brahmnicul 
doctrines relating to obsequies ceremonies the performance of sharadhas and the offering of ablution for the salivation of the soul of the deceased. Long association with Hindus, who form the bulk of the population, Jainism has assimilated several of the customers and ceremonial practice of the Hindus. But this no ground for applying the Hindu Law on Jainism. Jainism has an origin and history long and anterior to the Smrities and commentaries which are recognized authorities on Hindu law and usage.

There are some mistakes which even done by framers of education policy for India, In 1926, the reformer Hem Chandra Rai noted in the Jain Gazette that a "dark gloom of ignorance is stunting the growth of our community to a fearful extent all around. ..." . If you tell a Jain person in legal sense a Hindu, and in schools one also gets wrong education then he himself comes at a conclusion that he is a Hindu not a Jain, and this will severely damage the religion at very large, because the basic ideology is differ in both of the religion they are totally opposite of each other.

Bearing the above anticipated question in mind, as well as the possible plausible answer written from the neutral perspective of an outsider, it argues that a misplaced notion or notional ideas that Jainism is a part and parcel of Hinduism and therefore fit it in Hindu laws.

In the Buddhist scripture Majjima Nikaya, Buddha himself tells us about his ascetic life and its ordinances which are in conformity with the Jain monk's code of conduct. He says, "Thus far, SariPutta, did I go in my penance? I went without clothes. I licked my food from my hands. I took no food that was brought or meant especially for me. I accepted no invitation to a meal." Mrs. Rhys Davis has observed that Buddha found his two teachers Alara and Uddaka at Vaisali and started his religious life as a Jain. In Dighanikaya's Samanna Phal Sutta, the four vows of Lord Parshvanath (who flourished 250 years before Mahavira's liberation) have been mentioned. Attakatha of Anguttara Nikaya has reference to Boppa Sakya a resident of Kapilvastu who was the uncle of Buddha and who followed the religion of the Nigganathas i.e. Jains.

Some historians think that Jainism existed, no doubt, much prior to Buddhism, but it is a protestant creed which revolted against the sacrifices of the Vedic cult. The advanced researchers show that the above stand has no foundation. The respectable and reliable sacred books of the Hindus themselves establish the most ancient nature of Jain thought. Rigveda, the oldest Hindu scripture refers to Lord Rishabha Deo, who was the founder of Jainism. It also talks about Vaman Avtar-incarnation, who is the $15^{\text {th }}$ incarnation amongst the 24 incarnation. Rishabha's name comes as the $9^{\text {th }}$ incarnation Vishnu. Rishabha's name occurs before Vaman or Dwarf Ram, Krishna, and Buddha incarnations. Therefore it is quite clear that Rishabha must have flourished long before the composition of Rigveda. The great scholar Dr. S. Radhakrishnan, ex-president of Indian Union, in his 'India Philosophy' had observed, "Jain tradition ascribes the origin of the system to Rishabhadeva, the first Tirthankara. There is no doubt that Jainism prevailed even before Vardhaman or Parsvanath. The Yajurveda mentions the name of three Tirthankaras-Rishabha, Ajitnath and Arshtanemi. The Bhagwat Puran endorses the view that Rishabhadeva was the founder of Jainism."

The excavations made at Mohenjodaro and Harappa show that Jainism existed five thousand years ago, because the pose of the standing deities on the Indus seals resembles the pose of standing image of Rushabhadeo obtained from Mathura. The feeling of abandonment that characterizes the standing figure of the Indus seals, three to five (Plate II, I G.N.) with a bull in the foreground may be the prototype of Rishabha. (Modern review Agust 1932 - Sindha Five Thousand Years Ago) The poet Jinasena in his Mahapurana has spoken of Rishabha as Yogishwara. Therefore, the Indus valley excavated material glaringly establishes the fact that the founder of Jainism belonged to the pre-Vedic period. The nude Jain idol of 320B.C. in Patna Museum, of Lohanipur helps us to support the above contention.

A glance over the glorious past of Jainism reveals the fact that the lives of Rishabhadeo and the succeeding twenty-three Tirthankaras had deeply impressed the entire world culture. When the Alexander invaded India he came across a host of nude Jain saints in Taxila whom the Greek writers call 'Gymnosophists.' The Greek word connotes the nude philosopher. The mystic group of Israel, called the Essenes, was much influenced by these 'Gymnosophists', who were preaching their message of Ahimsa, the central truth in Jainism to the people of Alexandra in Egypt. Historical records tell us that the Greeks were much influenced by Jain thoughts. Alexander had taken one Jain saint, Calanes, with him to his country.

It is to be noted that the Essenes of Israel were ascetics who followed the tenets of Ahimsa. They had great hold upon the people and they commanded deep influence in Palestine. John the Baptist was an ascetic teacher of this school of Essenism. Jesus Christ, the founder of Christianity was much influenced by John's Non-violence group and other teachers of Essenism. In six hundred B. C. this group of Non-violence was progressing beyond Syria and Palestine. The Jain teachings have also influenced Pythagoras, the philosopher of pre-Socratic period, who flourished in 532 B. C. and led the non-violence way of life. During this period Lord Mahavira, the $24^{\text {th }}$ Tirthankara, whom the ignorant people called the founder of Jainism, was living. Perhaps Lord Mahavira's teaching had influenced the people of far off countries [6]. 


\section{View of leaders at the time of independence:}

The point that Jainism is not an off shoot of Hinduism was made clear by our late leaders and Prime Minister Pt. Jawahar Lal Nehru[7], wrote: "Budhist or a Jain in India is hundred percent of Indian thought and culture, yet neither is a Hindu by faith. It is entirely misleading to refer to Indian culture, as Hindu culture. Budhism or even Vedic Dharma"

Considering the Jain as a separate Community the President of the Constituent Assembly Dr.Rajendra Prasad nominated Shri Kasturbhai Lalbahi as a Jain representation to the Minister Advisory Committee. The Position was officially recognized in a letter No. 23/94/50 P. M.S. New Delhi dated- /3/50 from the Principal Private Secretary of the Prime-Minister to Shri S. G. Patil representative of the Jain deputation which waited on the Prime Minister Sh. Nehru on 25th January, 1950.

It reads:- "With reference to the deputation of certain representatives of the Jain who met the Prime Minister on the 25th January, 1950, I am desired to say that there is no cause whatever for Jains to have any apprehension regarding the future of their religion and community. Your deputation drew attention to the article 25 of constitution. The constitution only lays down a rule for limited purpose of the provision in the Article and as you will notice, it mentions not only Jains but also Budhists and Sikhs. It is clear that Budhists are not Hindus. There is therefore no reason for thinking that Jains are considered as Hindus. It is true that Jains are in some ways closely aliked ;to Hindus and have many customs in common but there is no doubt that they are a distinct religious community and the constitution does not in any way effect this well recognized position. "Why then Jains are now come under Hindu laws?

"There is nothing wonderful in my saying that Jainism was in existence long before the Vedas were composed" Dr S. Radhakrishnan[8]

Jainism has an origin and history much anterior to the smritis[9]. Jainism rejects the authority of the Vedas and discards all ceremonies and rituals. Jainism does not believe in the existence of god. It holds that by tapasya, by discarding worldly life and its worldly manifestation, atma can become parmatma and thus one can attain salvation (moksha). Both the codified and uncodified hindu law applies to Jains[10], THEN WHY Jains are take as an integral part of hindu laws.

Dr. Rabindra Nath Tagore in his reputed National Anthm Jana, Gana, Mana, enumerates Jains, Budhists , Musims, Parsees and Hindus as different 'people', who inhabit India. The lines referred to are; "Day \& night, the voice goes out from land to land calling Hindus, Budhists, Sikhs \& Jain and Parsees, Musalman \& Christians authority throne. Offering are brought to thy shrine by the East \& West to be woven in a garland of love. Then dispenser of India's destiny, Victory, Victory, Victory to thee".

\section{History of Jain law}

The nineteenth century English neologism 'Jain law' is a product of colonial legal intervention in India from 1772 onwards. 'Jain law' suggests uniformity where in reality there is a plurality of scriptures, ethical and legal codes, and customs of sect, caste, family and region. The contested semantics of the term reflect alternative attempts by the agents of the modern Indian legal system and by Jain reformers to restate traditional Jain concepts. Four interpretations of the modern term 'Jain law'[11] can be distinguished:

(i) 'Jain law' in the widest sense signifies the doctrine and practice of Jain dharma, or Jain 'religion'.

(ii) In a more specific sense it points to the totality of conventions (vyavahāra) and law codes (vyavasthā) in Jain monastic and lay traditions. ${ }^{11}$ Sanskrit vyavasthā and its Arabic and Urdu equivalent $q \bar{a} n \bar{u} n$ both designate a specific code of law or legal opinion/decision, whereas Sanskrit dharma can mean religion, morality, custom and law.

(iii) The modern Indian legal system is primarily concerned with the 'personal law' of the Jain laity. In AngloIndian case law, the term 'Jain law' was used both as a designation for 'Jain scriptures' (śästra) on personal law, and for the unwritten 'customary laws' of the Jains, that is the social norms of Jain castes (jāti) and clans (gotra). (iv) In 1955/6 Jain personal law was submerged under the statutory 'Hindu Code', and is now only indirectly recognized by the legal system in the form of residual Jain 'customs' to be proved in court.

The principal written sources for judging the proper conduct of the laity are the medieval śrāvakācāras, treatises containing rules of conduct ( $\bar{a} c \bar{a} r a)$ for the laity (śrāvaka), and nītiśāstras, texts on statecraft, law and ethics. The Sanskrit term nitti-śástra is used as a designation for both texts on statecraft and political ethics (rājja$n \bar{i} t i)$ and for texts on morality and rules for ethical conduct in everyday life (sāmānya-nīti). Together, the śrâvakācāras and the nittiśāstras form the Jain equivalent of the Hindu dharmaśástras. But their focus is more on ethics and ritual than on statecraft and personal law, which are traditionally kept outside the religious law and left to local custom, deśācāra, which Jains are advised to observe if there is no conflict with the dharma.

Prakrit Languages: The meaning of 'Prakrit' is 'Natural'. The word prakrit is used for a group of languages spoken in ancient India. Jainism has a great relation with Prakrit Languages. In ancient India Sanskrit was 
spoken only by Vedic Brahmins, while common people's language was Prakrit. Jains always promoted their religion through people's languages. So most of ancient Jain literature was written in Prakrit Languages.

The principal sources of Jain law are the Prakrit Śvetāmbara and Digambara scriptures, known as aggama or siddhänt $t^{l}$, and their extensive commentaries. The majority of the texts were created by monks of the Digambara tradition which had a sustained influence on the ruling dynasties in the Deccan between the 8th-12th centuries. The most significant Jain works on statecraft are the Ādipurāna of Ācārya Jinasena (ca. 770-850 C.E.) and the Nìtivākyāmrrtam (ca. 950 C.E.) and the Yaśastilaka (959 C.E.) of Ācārya Somadeva Sūri. Both authors were associated with the rulers of the Rāștrakūṭa Empire. The Ádipurāna belongs to the genre of universal history.

It tells the life story of the first Jina, the legendary first king and law-giver Rișabha, in the manner of a Jain Mahābhärata, and for the first time offers blueprints for Jain social rituals and Jain kingship through the Jainization of Brāhmanical prototypes. The Nìtiväkyämrtam, by contrast, is an entirely secular text on statecraft modelled on the Ârthaśāstra of Kautilya (ca. 3rd century B.C.E. - 1st century C.E.) with barely noticeable emphasis on Jain morality. The most influential medieval Śvetāmbara text concerning the laity is the Yogaśāstra and its auto-commentary by Hemacandra (12th C.E.) who was closely linked with King Kumārapāla of the western Cālukya dynasty in Gujarat. The first Śvetāmbara text detailing life-cycle rituals is the Ācäradinakara of Vardhamānasūri of the Kharatara Gaccha (1411 C.E.).

Compilations of 'Jain law' texts produced by modern Jain reformers in the 19th and early 20th centuries focused exclusively on the only legal domain which was initially exempted from codified Anglo-Hindu law, that is the rules of Jain 'personal law' concerning the role of property in contexts of marriage, adoption, succession, inheritance, and partition. At the centre of concern was the division of property, or däya-vibhägam. Medieval Digambara texts with chapters on 'personal law' are the Bhadrabāhu Samhitā (ca. 8th-15th century C.E.), the Vardhamānanīti of Amitagati (ca. 1011 C.E.), the Jina Saṃhitā of Vasunandi Indranandi(10th century C.E.), and the Traivarnikācāra of Somasena (1610 C.E.). The pioneering Bhadrabāhu Saṃhitā was cited by all later texts, even by treatises of Śvetāmbara authors such as the Arhannīti of Hemācārya (12th-14th century C.E.). They usually follow the example of Brāhmanical works such as the Manusmrti (ca. 2nd century B.C.E. - 1st century C.E.), which in parts is influenced by earlier Jain teaching as Derrett [12] for instance on Manu 6.46 has shown. The Jain texts also contain many original conceptions especially on the rights of widows to inherit and to adopt a son, coloured throughout by the Jain value of non-violence.

Reform oriented 'liberal' Jain lawyers resisted the imposition of Anglo-Hindu law, which from 1858 was extensively codified, and the progressive juridical demotion of the notion of a scripture based uniform 'Jain law', mirroring śästric 'Hindu law', and its replacement with secular unscripted local 'customs' of caste. They persistently demanded the "right for a personal law based on our scriptures" (Alaspurkara 1945: 1). For the purpose of unifying 'the Jain community' to strengthen its political influence, the fiction of a long forgotten originally unified 'Jain law' was upheld:

"The Jains, if they are not now, have been a united body of men and women, at least in the Past. They had a law of their own. It is not altogether lost. It is buried in the mass of our literature and traditions; but it is there all right".

"All the Jains are governed by one law. The laws books to which they owe and profess allegiance are the same. The spiritual precepts which form the backbone of their moral and mundane conduct spring from the same theological and metaphysical beliefs and considerations" [13];

"It is well to recognize that the Jains are not a bagful of castes and sects with diversified cultures, conceptions and creeds. There is one doctrine, one religion, one culture, one community of the Jains, and also one Law" [14].

Because no textual evidence was accessible to the courts during the period of codification of Hindu law, Jain law was treated merely as a 'deviation' from standard 'Hindu law'. 'Jainism/Jinism' was not even recognised as an independent 'religion' until 1879 when Hermann Jacobi in the introduction of his edition of the Kalpasutra of Bhadrabāhu furnished for the first time textual proof that the ancient Buddhist scriptures already depicted the nirgranthas as a separate 'heretical' (tìrthyā) group. Officially, the category 'Jain' was used for the first time in the Census of India of 1881.

The legal status of the Jain laity continued to be disputed until Indian Independence. However, the Privy Council decision on Bhagawandas Tejmal v. Rajmal effectively sealed the legal position of the Jain's in India today. Its decision that the Jain's come under codified 'Hindu law' dominated the case law until 1955/6 when 'Jain law' was officially subsumed under the new statutory 'Hindu Code' (which grants the same rights to widows as the Jain texts centuries ago) with the dispensation that Hindu law is to be applied to Jains in the absence of proof of special customs. Article 25 (2) b Explanation II of the Constitution of India recognises Jains, Sikhs and Buddhists as separate religious groups, but subsumes them into 'Hindu' law, as do Sections 2 of the Hindu Marriage Act of 1955 and the Hindu Succession Act of 1956, as well as the Hindu Minority and Guardianship Act and the Hindu Adoptions and Maintenance Act of 1956. 
Despite their different religious beliefs and practices, for all practical purposes 'Jain' is treated as 'Hindus' by the Indian state. Jains were not even granted religious 'minority' status after the introduction of the National Commission of Minorities Act of 1992, except on the basis of differential state legislation. The controversial judgment of BalPatil v Union of India (AIR 2005 SC 3172) states: "'Hinduism' can be called a general religion and common faith of India whereas 'Jainism' is a special religion formed on the basis of quintessence of Hindu religion."

The process in modern Indian legal history of narrowing the semantic range of the modern term 'Jain law' from 'Jain scriptures' down to 'Jain personal law' and finally 'Jain custom' may thus culminate not only in the official obliteration of Jain legal culture, which continues to thrive outside the formal legal system, in monastic law, ethics and custom, but also of Jain 'religion' were not even granted religious 'minority' status after the introduction of the National Commission of Minorities Act of 1992. The artificial political issue whether Jains are Hindus or not is largely based on (deliberately) ambiguous legal definitions [15].

'If a Hindu be defined as one born in India, or at the best one born in India and who was not a Mahomedan or Christian by birth then certainly every Jain is a Hindu. - Some say Hindu is one from whom injury (Him-sa) is removed (Du-r). If this is so, only Jains are the first and best Hindus; whereas meat eating, hunting Hindus will not be Hindus at all. Others say, - a Hindu is one who owes allegiance to the Vedas or the Brahman. There again Jains are not Hindus. Really it is an idle and futile problem.

To raise the communal self-awareness amongst Jains, British educated Jain reformers campaigned from the mid 19th century onwards for the public self identification of the Jains as 'Jains', particularly at the time of the Census when many Jains, for one reason or another, still identify themselves as 'Hindu'.

\section{Cases related to Jains as separate need for code}

If Sikhism, Jainism and Buddhism are separate and distinct religions, can followers of these faiths be bracketed as Hindus under the Constitution and be governed by Hindu personal law, the Supreme Court asked before issuing notice to the Centre and attorney general G E Vahanvati. Sikh scholar Birendra Kaur in her petition questioned the constitutional and past legislative attempts to obliterate identities of separate faiths by recognizing them under the broad religious connotation of Hindus. She said this negated the constitutional guarantee to each individual to practise and propagate the religion of his/her choice.

'Kaur's petition an expression of frustration' The Punjab and Haryana high court had dismissed with caustic observations a petition by Sikh scholar Birendra Kaur questioning the constitutional and past legislative attempts to obliterate identities of separate faiths by recognizing them under the broad religious connotation of Hindus, but an SC bench of Chief Justice Altamas Kabir and Justices S S Nijjar and J Chelameswar not only entertained her appeal but also framed the question for adjudication.

"This petition is seeking to express and make clear the frustration and disappointment of a large part of the Sikh community which feels its identity as Sikh is undermined by certain clauses and titles of certain statutes which club Sikhs under the definition of Hindu," senior advocate Colin Gonsalves argued.

The SC said, "Issue notice on the question as to whether the inclusion of people professing the Sikh, Jain or Buddhist faiths could be included in the enactments relating exclusively to persons professing the Hindu religion, within the ambit of Explanation II to Article 25(2) of the Constitution. Let notice be issued separately to the AG also, to be served both through the ministry of minority affairs as also through the central agency, returnable six weeks hence." However, the petitioners said a constitutional mischief arose through Explanation II, which said, "The reference to Hindus shall be construed as including a reference to persons professing the Sikh, Jain or Buddhist religion, and the reference to Hindu religious institutions shall be construed accordingly." The petition said making a law applicable to all religions was one thing but it would be discriminatory to refer different religions by the name of a religion.

The petitioner added, "The Hindu Marriage Act, 1955, the Hindu Succession Act, 1956 and the Hindu Minority and Guardianship Act, 1956, use the word Hindu to include Sikhs, Buddhists, Jains and others, even though it is clarified that these are separate religions." Would it be acceptable if the name of the Hindu Marriage Act was changed to Buddhist Marriage Act and made applicable to all four religions, the petitioner asked.

The controversial judgement of Bal Patil v Union of India (AIR 2005 SC 3172) states:

"'Hinduism' can be called a general religion and common faith of India whereas 'Jainism' is a special religion formed on the basis of quintessence of Hindu religion." BUT Not an offshoot of Hinduism:- Some oriental scholars, who are not well acquainted with Jain literature once held the erroneous view that Jainism is an offshoot of Hinduism. This view mainly as the result of the researches made by Dr. Herman Jacabi a German scholar, has now been given up. He says:

"Jainism has a metaphysical basis of its own, which secured it a distinct position apart from the rival system is both of the Brahmans and the Buddhists. Now I have never been of the opinion that Jainism is an original system of religion quite distinct and independent of philosophical thoughts and religious life in ancient India.(Jain Gazette 1927, P 105). 
AS IN THE BEGINNING IT is proof Jainism is older than Hinduism. Mr. Justice Rangnekar of the High Court of Judicature of Bombay, vide A.J.R. 1039, Bombay 377observer.

"It is true the Jain reject the scriptural character of the Vedas and repudiated the Brahmnical doctrines relating to obsequail ceremonies the performance of sharadhas and the offering of ablution for the salavation of the soul of the deceased. Amongst them there is no belief that a son by birth or adoption confers spiritual benefit on the father. They also differ from the Brahmnical Hindus intheir conduct towards the dead; omitting all obsequies after corps is burnt or buries. Now it is true as latter historical researches have shown that Jainism prevailed in the country long before Brahminism came into existence or converted into Hinduism.It is a also true that owing to their long association with the Hindus, who formed the majority in the country, the Jains have adopted many of the customs and even ceremonies strictly observed by the Hindus and pertaining to Brahmical religion."

Justice Kumar-Swami Shastri marks the following remarks in 50 Madras pp. 228 and 230. "Were the matter res-intgra, I would be inclined to hold that the Jains are not Hindu dissenters but that Jainism has an origin and history long and anterior to the Smrities and commentaries which are recognized authorities on Hindu law and usage. In fact, Mahavira, the last of the Jain Tirthanakas, was a contemporary of Budha and died about 527 B.C. The Jain religion refers to a number of previous Tirthankara and there can be little doubt Jainism as a distinct religion was flourishing several centuries before Christ. In fact, Jainism rejects the authority of the Vedas which form the bed-rock of Hinduism and denies the efficiency of the various ceremonies which Hindus consider essential; so far as Jain law is concerned it has its own law books of which Bhadra Bahu Samhita is an important one. Vardhman Neeti by great Jain teacher Hemchandra deals also with Jain law. No doubt, by long association with Hindus, who form the bulk of the population, Jainism has assimilated several of the customers and ceremonial practice of the Hindus. But this no ground for applying the Hindu Law as developed by Vijayaneshwar and other commentators.

Several centuries after Jainism was a distinct and separate religion with its own religious with its own religious ceremonial \& legal system, unblock to Jains, and throwing on them the right showing that they are bound by the law as laid down by the Jain law-makers. It seems to me that in considering the question of Jain Law, relating to adoption, succession and partition we have to see what the law expounded by the law gives is, and to throw the onus on those assert that in any particular matter the Jains have adopted the Hindu Law \& customs and have not followed the law as laid down by their own Shstras.

All India Reporter 1927 Bombay, 185 (189) Sugan Chand Bhic Chand versus Magni Bhai Gulabchanda.

"In view of the aforesaid arguments \& evidences of the eminent Scholars the following arguments of the government of Bombay to include Jains in the category of Hindus that "All legislation which is intended for the benefit or uplift of Hindu society has in the past been made applicable to Jains also without discrimination, does not stand to reason on equality and justice. True devotee of truth $\&$ non violence should not take pride in his past mistaken notions rather he is expected to rectify this erroneous stand as early as possible.

\section{Chronological order of various court judgments on Jainism as a separate religion}

1927 - Madras High Court in Gateppa v. Eramma and others reported in AIR 1927 Madras 228 held that "Jainism as a distinct religion was flourishing several centuries before Christ". Jainism rejects the authority of the Vedas which form the bedrock of Hinduism and denies the efficacy of the various ceremonies which Hindus consider essential.

1939 - In Hirachand Gangji v. Rowji Sojpal reported in AIR 1939 Bombay 377, it was observed that "Jainism prevailed in this country long before Brahmanism came into existence and held that field, and it is wrong to think that the Jains were originally Hindus and were subsequently converted into Jainism."

1951 - A Division Bench of the Bombay High Court consisting of Chief Justice Chagla and Justice Gajendragadkar in respect of Bombay Harijan Temple Entry Act, 1947 (C.A. 91 of 1951) held that Jains have an independent religious entity and are different from Hindus.

1954 - In the Commissioner Hindu Religious Endowments, Madras v. Sri Lakshmindra Thirtha Swamiar of Sri Shirur Mutt reported in AIR 1954 SC 282 this Court observed that there are well known religions in India like Buddhism and Jainism which do not believe in God, in any Intelligent First Cause. The Court recognized that Jainism and Buddhism are equally two distinct religions professed in India in contrast with Vedic religion.

1968 - In Commissioner of Wealth Tax, West Bengal v. Smt. Champa Kumari Singhi \& Others reported in AIR 1968 Calcutta 74, a Division Bench of the Calcutta High Court observed that "Jains rejected the authority of the Vedas which forms the bedrock of Hinduism and denied the efficacy of various ceremonies which the Hindus consider essential. It will require too much of boldness to hold that the Jains, dissenters from Hinduism, are Hindus, even though they disown the authority of the Vedas"

The lasting impact of the statutes of medieval codified Jain personal laws on the customs of Jain castes is evident in numerous reported cases of the 19th and 20th centuries. These cases cannot be dismissed as modern fabrications, despite their somewhat artificial identification of modern customs with ancient śāstric 
prescriptions, which was typical for early 19th century Anglo-Indian law, Already the earliest reported case on 'Jain law', Maharaja Govind Nath Ray v. Gulab Chand (1833 5 S.D.A. [Śadra Dīvān-i 'Adālat] Calcutta Sel. Rep. 276), concludes that "according to Jain Sastras, a sonless widow may adopt a son, just as her husband" (citing an untraceable passage in the Ācāradinakara).

\section{Differences between Jain laws and hindu laws}

Werner Menski [16] explores the role of Jain law under British colonial rule as well as in postIndependence India. Menski highlights the fact that conciliatory offers by the British to ascertain "Jain Law" through an examination of their sacred texts were largely rebuffed by Jains, and as a result Jains, as a community distinct from Hindus, tended to become functionally invisible; furthermore, Jains showed a marked reluctance to participate in the Anglo-Indian courts. Since the Hindu Marriage Act of 1955-56, in which Jains, Buddhists, and Sikhs were lumped together under so-called Hindu Law, this situation has not changed. Menski suggests, however, that an unofficial "Jain Law" has functioned and continues to function in unreported lowcourt decisions and in extra-judicial arenas, but so little data have been collected thus far that the extent of application of any such unofficial Jain Law in practice is yet a matter of speculation in Harnabh Pershad v. Mandil Das 27 C. 379 (1899) "the homogeneity of the Jains was recognized by holding that Jain customs of one place were relevant as evidence of the existence of the same custom amongst Jains of other places" .

\section{(a) Oaths and affirmation}

We take the view that the question of whether the administration of an oath is lawful does not depend upon what may be the considerable intricacies of the particular religion which is adhered to by the witness. It concerns two matters and two matters only in our judgment. First of all, is the oath an oath which appears to the court to be binding on the conscience of the witness? And if so, secondly, and more importantly, is it an oath which the witness himself considers to be binding upon his conscience?

Lord Lane C.J. in R. v. Kemble [1990] 91 Cr. App. R. 178 (emphasis added)

Jains

$\square$ May choose either to affirm, or possibly swear an oath.

Since there are many different groupings, no single text can be specified, but some may choose to swear an oath on a text such as the Kalpa Sutra. Sometimes such a witness will swear an oath by elevating a holy scripture above their head and swearing by it. If such a witness does not stipulate such a practice and does not have the appropriate text in court, they should affirm.

Questions of ritual purity may arise.

Even in England, Jains have their religious books as kalpa sutra not bhagwat gita[17].

\section{(b) Jain law of adoption}

Bhadrabahu Samhita: Jain Law by Acharya Bhadrabahu, Translated by J.L. Jaini states more than 100 rules related to adoption, separation, property distribution, partition etc in Jain's families are as follows in brief:

1. In the world, the existence of a son is such a source of happiness that, in the absence of a son, one's birth if fruitless, and a son is taken in adoption by men.

2. If a man has many brothers, and if they are one mind, it is due to his great punya (religious merit). So the great Risis (ascetics) have said!

3. Because of the decline in religious merit, those many brothers for greed of wealth entertain hostile feelings. To remove this trouble, this Law of Partition in undertaken.

4. On the death of father and mother, all those brothers get together the patrimony and divide it equally among themselves. But during the lifetime of the father (the brothers take only), according to the desire of the father.

:

:

111-112. If a son dies in the life-time of his parents, his chaste wife has no right, like him, in the grand-father's property. But preserving the husband's bed, fixed in her religion, the widow should, with head bowed down, beg the mother-in-law for a son.

113. If the husband's property is placed in the hands of the father-in-law and mother-in-law, the widow cannot claim it; she can only take what the late husband gave her.

114. If the widow with this permission takes a boy in adoption, she must take one of the same families, younger than herself and possessed of all qualities.

115. In the Jain sacred procession, in the image installation ceremony, and in similar religious deeds, and in the bringing up of the family, the widow has power to spend. But in nothing else she has the power to spend.

116-117. Thus, briefly, the rules of Inheritance and Partition have been narrated by me substantially from the Upasakadhyayana, in order to remove troubles and quarrels. Having read this, if one performs public (kingly) duties, one will get praise and reverence in this and a good gati (condition of existence) in the next world. 


\section{(c) Jain law of succession}

The leading case is Bhagawandas Tejmal v. Rajmal Bhagawandas Tejmal v. Rajmal (1873 10 Bom HC 241), a succession dispute within a Marwari Jain Agraval family involving a widow's right of adoption. Adjudicated by C. J. Westropp at the Bombay High Court, the decision was confirmed by the Privy Council in Sheosingh Rain v. Dakho (1878 ILR Allahabad 688). The final judgment distinguished between 'Jain law' and 'custom', but affirmed Westropp's view that the Jains come under Hindu law unless they are able to provide evidence for the prevalence of different customs:

"But when among Hindus (and Jains are Hindu Dissenters) some custom, different from the nor-mal Hindu law of the country, in which the property is located, and the parties resident, is alleged to exist, the burden of proving the antiquity and invariability of the custom is placed on the party averring its existence" (Bhagawandas Tejmal v. Rajmal 187310 Bom HC 260).

The Jains were and remain exempted from all those provisions of the Indian succession act 1925 which are inapplicable to the hindus, Buddhists and Sikhs. Part VI of the act read with schedule III.

If a Jain marries a Buddhist, Sikh or Hindu, whether by religious rites or as a civil marriage, succession to his property is governed (since1976) by the hindu succession act 1956, but by the Indian succession act 1925 if he marries a Christian, Muslim, Jew or Bahia. What a disturbance it is creating as of Jain,the earlier 3 religions are also same distant as the later.

A Jain succession act was enacted in the madras state in 1930. After the reorganization of states it became applicable to various areas of Andhra Pradesh, Karnataka, Kerala, and Tamil nadu carved out of the former madras state. Its status after the extension of the hindu succession act was not clear.

Vardhman Neeti by great Jain teacher Hemchandra deals also with Jain law. No doubt, by long association with Hindus, who form the bulk of the population, Jainism has assimilated several of the customers and ceremonial practice of the Hindus. But this no ground for applying the Hindu Law as developed by Vijayaneshwar and other commentators (succession).

Several centuries after Jainism was a distinct and separate religion with its own religious with its own religious ceremonial \& legal system, unblock to Jains, and throwing on them the right showing that they are bound by the law as laid down by the Jain law- makers. It seems to me that in considering the question of Jain Law, relating to adoption, succession and partition we have to see what the law expounded by the law gives is, and to throw the onus on those assert that in any particular matter the Jains have adopted the Hindu Law \& customs and have not followed the law as laid down by their own Shstras.

\section{(d) Marriages}

Among the Jains, the main purpose of marriage is to maintain the continuity of human race by getting legitimate children. Here the institution of marriage is viewed clearly in its social aspect. There is no religious motive whatsoever in the contracting of marriage as such. The necessity of marriage arises to provide a legitimate outlet to sexual feelings and to maintain the continuity of human race. Both purposes are served by regulating the sexual behaviour of people through the institution of marriage. That is why among the Jains, like Hindus, vivaha or marriage is generally considered as obligatory for every person and it is included in the Sarirasamskaras (i.e., sacraments sanctifying the body) through which every man and woman must pass at the proper age and time.

Though Jains and Hindus regard marriage as obligatory for every person, there is a great difference in their outlook in regarding so. While Jains look at the problem from a purely social point of view. Hindus treat if from a religions point of view. Among the Hindus marriage is made compulsory for every person because the birth of a son is said to enable one to obtain Moksa. Again, it is believed by Hindus that one's progeny is considerably connected with and instrumental to happiness both in this world as well as hereafter. Moreover, the birth of a son is conceived by Hindus to be especially contributory towards helping the father to execute his obligations due to the departed ancestors - one of the three debts or obligations which every Hindu is bound to discharge. A Hindu has to marry and to beget a male child with a view to a void eternal damnation in hell after his death.

According to Hindus, there is an intimate connection between marriage and the ultimate object in life viz., Moksa. As marriage has something to do with the emancipation of soul, marriage and religion are very closely connected with one another in Hindu society. Thus, the institution of marriage among Hindus loses its entirely social character, gets mixed up with religious behavior of the people and becomes a religious act as such.

In the Jain religion, on the contrary, marriage is not treated as a religious duty but is considered as a purely social act. It is regarded more in the nature of a civil contract than of a religious ceremony. Its object is to maintain the continuity of human race and not to obtain salvation by securing male offspring. Marriages are entered into for purely practical reasons and religion has nothing to order in this respect. It is not ordained in Jain religion to marry for emancipation of soul. Marriage is not concerned with life hereafter. When no offerings are to be made to the forefathers, the question of discharging obligations due to departed ancestors does not arise. Jain scriptures do not lay down elaborate rules and regulations regarding marriage. Marriage is completely based on customs of people designed to adjust the life of persons in this world as it is not concerned with the 
happiness of persons hereafter. If marriage among Jains would have been based on their Agamas (i.e., basic religious books), it would have been practically the same throughout many centuries and there would not have been great diversity of customs regarding various aspects of marriage throughout the country. Since marriage practices of Jains differ to a considerable extent, it is clear that the institution of marriage is based on local customs and not on Holy Scriptures. From this it need not be inferred that the Jain holy books do not refer to marriage at all. They do discuss the subject of marriage but in this respect their basic stand is that a lawful wife is necessary for a man for the successful completion of his house holder's life. They do not prescribe any rules regarding the matters like her age, qualifications, gotra, caste, race, etc., as these are based on local customs. There is practically little relation between marriage customs and Jain scriptures. It is true that sometimes we notice that in Jain books while narrating particular events, references are made and opinions given on the marriage customs connected with the events. But we cannot accept such opinions as applicable for all places and times since such opinions were given by taking into account marriage customs prevailing at that time. This means that marriage customs referred to in Jain books are not binding on Jains for all time to come and they are free to devise their own customs according to local conditions.

In Hinduism there is a direct connection between marriage and religion. In Jainism, however, there is an indirect connection between marriage, like any other custom, and religion. For Jains the ultimate object in life is the attainment of Moksa, i. e., liberation of soul from worldly bondage. The best way, according to Jainism, to achieve this aim is to perform right action along with right faith and right knowledge. The right action includes proper channelising of sexual practices with a view to lead and useful life which serves as a stepping stone for getting salvation. Moreover, religion depends for its existence on the number of its followers. The strength of the followers can be rightfully maintained through the procreation of legitimate children. Taking into account these considerations it can be stated that the object of marriage in Jainism is twofold, viz., (1) to give a legitimate outlet to sexual feelings so that the human being may rightly live a useful life, enjoying the fruits of Dharma, Artha and Kama, and thus be entitled to attain the great object - the Moksa; and (2) to promote the cause of Dharma (Law) by generating righteous and chivalrous sons and daughters. It is a duty of the householder to be contented with his own life and to contrive for the continuance of the human race[18].

NORMALITY OF MARRIAGE: Though marriage, according to Jains, is more in the nature of a civil contract than of a religious ceremony, it is enjoined upon every person to affect that contract. The Jain philosophy no doubt gives more importance to the policy of renunciation. The strict observance of celibacy throughout whole life is definitely more valued than indulgence in sensual pleasures. But it would be a mistake to suppose from this that Jainism is against marriage. Persons who lead a complete celebrate life are highly appreciated, yet those who cannot follow that path are not denounced. There are many people who cannot practice the strict life of renunciation and such persons are advised to get married as the next best course. That is why marriage has been included in the Sarirasamskaras (i. e., sacraments that sanctify body) through which every Jain must pass at the proper age and time. This arrangement, if not the fear of eternal damnation, as in the case of Hindus, makes it obligatory for every householder to give of his own accord his daughters in marriage before they attain puberty. Further, it has been ordained that those persons who will keep their grownup daughters in their homes without marrying them would fall from religion. In view of these injunctions parents rush in to contract the marriages of their children and as a result we find that in the Jain community child-marriage was the order of the day until a few years ago[18].

\section{Minority status}

Despite their different religious beliefs and practices, for all practical purposes 'Jains' are treated as 'Hindus' by the Indian state. Jains were not even granted religious 'minority' status after the introduction of the National Commission of Minorities Act of 1992, 1958 - In well known Kerala Education Bill's case, 1957 reported in AIR 1958 SC 956, this Court held that to claim the minority rights, the Community must be numerically a minority by reference to the entire population of the State or country where the law is applicable. In that way also, the Jain Community is eligible for the claim.

1976 - In Arya Samaj Education Trust, Delhi \& Others v. The Director of Education, Delhi Administration, Delhi \& Others reported in AIR 1976 Delhi 207, it was held as follows: "Not only the Constitution but also the Hindu Code and the Census Reports have recognized Jains to belong to a separate religion." In the said judgment, the Court referred to the observations of various scholars in this behalf. The Court quoted Heinrich Zimmer in "Philosophies of India" wherein he stated that "Jainism denies the authority of the Vedas and the orthodox traditions of Hinduism. Therefore, it is reckoned as a heterodox Indian religion". The Court also quoted J. N. Farquhar in Modern Religious Movements in India wherein he stated that "Jainism has been a rival of Hinduism from the beginning". In the said judgment, in conclusion, the Court held that "for the purpose of Article 30(1), the Jains are a minority based on religion in the Union Territory of Delhi". 
1993 - In A.M. Jain College v. Government of Tamil Nadu (1993) 1 MLJ 140, the Court observed that it is also an admitted fact that the Jain community in Madras, Tamil Nadu is a religious and linguistic minority.

List of states in which Jains have been declared as minority:

1. Maharashtra (which has the largest population of Jains in India) ,2. Karnataka, 3. Madhya Pradesh,

4. Uttar Pradesh 5. Jharkhand 6. Delhi 7. Uttarakhand 8. West Bengal 9. Andhra Pradesh 10. Haryana

11. Punjab 12 . $\underline{\text { Assam }}$

Chatissgarh government denied minority status to Jains on 19th june 2013 which was earlier granted by congress government.

(Officially, the category 'Jain' was used for the first time in the Census of India of 1881. The Census still remains the only government institution which classifies the Jains as a separate religious group. Despite the legal recognition of the doctrinal differences between 'Hinduism' and 'Jainism' in the landmark judgement Gateppa v. Eramma AIR 1927 Madras 228, 'Jain law' remains incorporated within 'Hindu law', and for all practical purposes Jains are treated as 'Hindus' by the Indian (UK and US) Government and were not even granted religious 'minority' status after the introduction of the National Commission of Minorities Act of 1992. The artificial political issue whether Jains are Hindus or not is largely based on (deliberately) ambiguous legal definitions.

Despite their different religious beliefs and practices, for all practical purposes 'Jains' are treated as 'Hindus' by the Indian state. Jains were not even granted religious 'minority' status after the introduction of the National Commission of Minorities Act of 1992, except on the basis of differential state legislation.

\section{(a) History of Jain demand for minority status}

The Jain demand for minority status is almost a century old, when in British India the Viceroy and Governor General of India, Lord Minto took a decision in principle of giving representation to important minorities in the Central Legislature. Seth Manek Chand Hirachand from Mumbai, an eminent Jain leader from Mumbai and the then Acting President of the Bharatvarshiya Digamber Jain Subha made an appeal in 1909 to the Governor General for the inclusion of the Jain community for representation in the Council. Seth Manek Chand's petition was transferred to the Government of Bombay and the Secretary to the Government of Bombay stated in his reply dated 15 October 1909 as follows:

"I am directed to inform you that a number of seats have been reserved for representation of minorities by nomination and that in allotting them, the claim of the important Jain Community will receive full consideration".

In a Memorandum by the Representative of the Jain Community to the Constituent Assembly in March/April 1947 a strong appeal was made for the inclusion of the Jain community as a minority religious community.

In his speech on 3rd Sept.1949, Jawahar Lal Nehru said: No doubt India has a vast majority of Hindus, but they could not forget in fact there are also minorities Muslims, Christians, Parsis and Jains. If India were understood as Hindu Rashtra it meant that the minorities were not cent per cent citizens of the country:

Jainism is mentioned as a religion along with Buddhism and Sikhism in explanation II of the Article 25 of the India Constitution relating to Fundamental Right to religions freedom. On this issue Jawahar Lal Nehru, the then prime Minister, in his letter dated 31.01.1950 assured a Jain Deputation that they need not have any misgivings on this clear constitutional position.

The second stanza of Jana Gana Mana, Indian National Anthem clearly enunciates Jainism as a separate religious denomination in line with Hinduism, Islam and other religions.

\section{(b) Recommendation of National Minorities Commission}

In 1993, the National Minorities Commission arrived at their recommendation that the Jain community be declared as a minority religious community. It was in consideration of the following:

- the relevant constitutional provisions,

- various judicial pronouncements,

- the fundamental differences in philosophy and beliefs (theism vs. atheism principally) vis-a-vis

Hinduism, and

- $\quad$ The substantial number of Jain population in the country.

It resolved to recommend to the Government of India that the Jains deserve to be recognized as a distinct religious minority, and that, therefore the Government of India may consider including them in the listing of "Minorities."

\section{(c) The Bal Patil Judgement}

Bal Patil, In 2005, the Supreme Court of India declined to issue a writ of Mandamus towards granting Jains the status of a religious minority throughout India. The Court however left it to the respective states to decide on the minority status of Jain religion.

In one of the observations of the Supreme Court, not forming part of the judgment, the Court said: 
“Thus, 'Hinduism' can be called a general religion and common faith of India whereas 'Jainism' is a special religion formed on the basis of quintessence of Hindu religion. Jainism places greater emphasis on non-violence ('Ahimsa') and compassion ('Karuna'). Their only difference from Hindus is that Jains do not believe in any creator like God but worship only the perfect human-being whom they called Tirthankar. Lord Mahavir was one in the generation of Thirthankars. The Tirathankars are embodiments of perfect human-beings who have achieved human excellence at mental and physical levels. In philosophical sense, Jainism is a reformist movement amongst Hindus like Brahamsamajis, Aryasamajisand Lingayats. The three main principles of Jainism are Ahimsa, Anekantvad and Aparigrah."

The Supreme Court also noted: " ... that the State Governments of Chhatisgarh, Maharashtra, Madhya Pradesh, Uttar Pradesh and Uttarakhand have already notified Jains as 'minority' in accordance with the provisions of the respective State Minority Commissions Act."

This cast a doubt on the independent standing of Jain religion. Scholars in the Jain tradition, as well as several groups amongst the Jain community protested, and emphasized that Jain religion stands as a religion in its own right. While Hinduism as a mode of living and as a culture is to be found across various religions in India because of several common customs, traditions and practices, but as religions Hindu religion and Jain religion are distinct.

U.P. Basic Shiksha Parishad Judgment: In 2006, the Supreme Court opined that "Jain Religion is indisputably is not a part of Hindu Religion".

(d) "Freedom of Religion Bill" controversy in Gujarat

The Freedom of Religion Bill was a controversial bill passed by the Gujarat state assembly. The bill was passed in 2003. An amendment to the bill was passed on 19 September 2006 which banned the forced conversion from one religion to another. The Anti-Conversion Act passed earlier was not clear on what forced conversion meant and to whom should it apply. Under the amendment Bill, a person need not seek permission in case he/she is converting from one sect to another of the same religion. It clubbed Jainism and Buddhism as denominations of Hinduism, like Shia and Sunnis are of Islam or Catholicism and Protestantism of Christianity. The move evoked strong protests from the state's Jain, Buddhist and Christian communities. The National commission for minorities also criticized the Gujarat Assembly's decision to club Jainism and Buddhism with Hinduism terming it to be in contravention of its 23 October 1993, notification classifying Buddhists as a "minority community."

Ultimately on 31 July 2007, finding it not in conformity with the concept of freedom of religion as embodied in Article 25 (1) of the Constitution, Governor Nawal Kishore Sharma returned back the Gujarat Freedom of Religion (Amendment) Bill, 2006. The Governor held that Jainism and Buddhism are recognized as religions rather than denominations of Hinduism, something that the Amendment Bill sought to wrongly convey. A press release issued by Raj Bhavan, said "the proposed amendment would amount to withdrawing the protection against forceful or inappropriate religious conversions, particularly in case of Jains and Buddhists". The release cited large scale protests from different religious and social organizations, especially from the Jain and Christian communities, in indicating toward the unacceptability of the proposed amendment.

\section{Conclusion}

By the above cited study of Jain Religion under different legal rules, supports that Jain religion should be accepted as separate entity in all manners. Jain legal rules not be taken as subset of Hindu law. To grow the Jain community completely, it is necessary that Jain Law must be exist like Hindu and Muslim law in legal system. Recently central government of India granted Jain's the status of a religious minority throughout India and start steps in this direction for Jain community.

\section{References}

[1] S Mukherji, K K Maltiar, S R Maltiar, and V Sukla, Our world then and now-2, (Bharti Bhawan Publisher and Distributers).

[2] H Zimmer, Myths and symbols in India Art and Civilization (Pathun Books inc., 1946).

[3] A L Basham A Cultural History of India (Clarendon Press, Oxford, 1975).

[4] H Zimmer, Philosophies of India (Princeton university press, 1969) .

[5] Buhler, Eminent orientalists (Cosmo publications, 2000).

[6] S C Diwakar, Glimpse of Jainism ( Shri Bharatvarshiya Digambar Jain Mahasabha, 1964)

[7] J L Nehru, Discovery of India (Penguin, 2008).

[8] S. R Radhakrishnan, Indian Philosophy-I (Oxford university pressUSA, 2008).

[9] Boddaladi vs Boddaladi, Per kumaraswami Sastri, J. (50 Mad 228, 1927).

[10] P Diwan, Modern hindu law (Allahabad Law Publisher, 1993).

[11] Flügel Peter, A short history of jain law, International Journal of Jain Studies 3(4), 2007, 1-15.

[12] J Derrett, Scrupulousness and a hindu-jain contract, Journal of the Royal Asiatic Society of GreatBritain and Ireland, 1980, $144-167$.

[13] J L Jaini , Jain law bhadrabahu samhita, (Central Jaina Publishing House, 1916). 
[14] C R Jain , A complete digest of cases with the jaina law supplement, (Delhi S B Jain Academy, 1941).

[15] Flügel Peter, The invention of Jainism, International Journal of Jain Studies 1(1), 2005, 1-14.

[16] M Werner, Jaina law as an unofficial legal system, in Flügel Peter (Ed.), Studies in Jain history and culture, (London:Routledge, 2006) 417-435.

[17] Equal Treatment Bench Book, chap 3.1 Discrimination on the basis of belief or non-belief, (London: Judicial studies board, 2009).

[18] V A Sangve, Jain Marriage- Status of woman, Jain religion and community, (Long beach pubns, 1997). 